\title{
Monitoring organic loading to swimming pools by fluorescence excitation-emission matrix with parallel factor analysis (PARAFAC)
}

Seredynska-Sobecka, Bozena; Stedmon, Colin; Boe-Hansen, Rasmus; Waul, Christopher Kevin; Arvin, Erik

Published in:

Water Research

Link to article, DOI:

10.1016/j.watres.2011.01.010

Publication date:

2011

Document Version

Early version, also known as pre-print

Link back to DTU Orbit

Citation (APA):

Seredynska-Sobecka, B., Stedmon, C., Boe-Hansen, R., Waul, C. K., \& Arvin, E. (2011). Monitoring organic loading to swimming pools by fluorescence excitation-emission matrix with parallel factor analysis (PARAFAC). Water Research, 45(6), 2306-2314. https://doi.org/10.1016/j.watres.2011.01.010

\section{General rights}

Copyright and moral rights for the publications made accessible in the public portal are retained by the authors and/or other copyright owners and it is a condition of accessing publications that users recognise and abide by the legal requirements associated with these rights.

- Users may download and print one copy of any publication from the public portal for the purpose of private study or research.

- You may not further distribute the material or use it for any profit-making activity or commercial gain

- You may freely distribute the URL identifying the publication in the public portal 
Submitted to: Water Research

1 Monitoring organic loading to swimming pools by fluorescence

2 Excitation-Emission Matrix with parallel factor analysis

3 (PARAFAC)

4

5 Bożena Seredyńska-Sobecka ${ }^{\mathrm{a}}$, Colin A. Stedmon ${ }^{\mathrm{b}}$, Rasmus Boe-Hansen ${ }^{\mathrm{c}}$, Christopher K.

6 Waul $^{\mathrm{a}}$ and Erik Arvin ${ }^{\mathrm{a}, *}$

8 a Department of Environmental Engineering, Technical University of Denmark,

$9 \quad$ Miljoevej, Building 113, 2800 Kgs. Lyngby, DK

10 (bozena@seredynski.org;cwaul@yahoo.com; erar@env.dtu.dk)

$11{ }^{\mathrm{b}}$ Department of Marine Ecology, National Environmental Research Institute, Aarhus

12 University, Frederiksborgvej 399, 4000 Roskilde, DK (cst@dmu.dk)

13 c Krüger A/S, Gladsaxevej 363, 2860 Søborg, DK (rab@kruger.dk)

15 Abstract Fluorescence Excitation -Emission Matrix spectroscopy combined with parallel

16 factor analysis was employed to monitor water quality and organic contamination in

17 swimming pools. The fluorescence signal of the swimming pool organic matter was low

18 but increased slightly through the day. The analysis revealed that the organic matter

19 fluorescence was characterised by five different components one of which was unique to

20 swimming pool organic matter and one which was specific to organic contamination. The

21 latter component had emission peaks at $420 \mathrm{~nm}$ and was found to be a sensitive indicator

${ }^{*}$ Corresponding author. tel.: +45 45251472; fax: +45 932850 
Submitted to: Water Research

22 of organic loading in swimming pool water. The fluorescence at $420 \mathrm{~nm}$ gradually

23 increased during opening hours and represented material accumulating through the day.

24 Keywords swimming pool, fluorescence, Excitation-Emission Matrix (EEM),

25 wastewater, parallel factor analysis (PARAFAC)

\section{1. INTRODUCTION}

28 Monitoring of water quality in swimming pools is important in order to avoid health risk

29 to swimmers and swimming pool staff. In general, there are three sources of organic

30 matter: the water supplied to the pool, a passive loading of organics leached from the

31 bodies of bathing guests, and a more direct loading of bodily wastes in the form of urine

32 and faeces. The latter is most harmful, however, both contribute to the organic loading

33 and hence the microbial quality in pools. Microbial safety of swimming pool water is

34 required by law (Directive, 2006). Moreover, the organic matter concentration should be

35 maintained low as it reacts with chlorine and produces a suite of chlorinated organic

36 compounds (e.g. trihalomethanes THMs) which are known to be harmful.

To be effective, a water quality monitoring system needs to detect

38 contamination at the initial stage. At present, for chemical and microbial water quality

39 monitoring, a combination of sampling and subsequent analysis is usually applied and

40 may not assure the health of the bathers. Therefore, there is a strong need for on-line

41 sensors providing immediate information on water quality which enables a quick

42 remedial action. Fluorescence might be a promising technique that fulfils the required

43 criteria. Fluorescent properties of organic matter have been widely studied in various

44 aquatic systems for many years (Coble, 1990; Muller et al., 2008; Henderson et al., 2009;

45 Johnstone et al., 2009). However, limited studies have been carried out on the 
Submitted to: Water Research

46 fluorescence properties of chlorinated aquatic organic matter and these have mainly been

47 focused on the chlorination of drinking (Fabbricino and Korshin, 2004; Johnstone and

48 Miller, 2009; Roccaro et al., 2009) and recycled water (Hambly et al., 2010 a,b). To our

49 knowledge, there is no information on fluorescent organic matter in swimming pools.

50 Drinking water purification studies suggest that in chlorinated waters organic matter

51 fluorescence will be low (Johnstone and Miller, 2009). In swimming pools, water has to

52 be disinfected with chlorine and adequate free chlorine level has to be maintained to

53 assure the microbial safety (Uhl and Hartmann, 2005). Chlorine dosages used for

54 swimming pool disinfection are higher than those applied in drinking water treatment.

55 Moreover, pool water is recycled and therefore chlorinated on continuous basis (Lee et

56 al., 2009). Due to fluorescence quenching properties of chlorine and its reactivity

57 (Henderson et al., 2009 and references therein), one can expect a very low background

58 fluorescence of swimming pool organic matter, which may be ideal for using

59 fluorescence to monitor for excessive organic loading, and indicate when further water

60 quality treatment or other intervention are required.

61 Based on this assumption, a series of experiments employing both swimming

62 pool and wastewater has been performed aiming at estimating the detection limit for

63 anthropogenic contamination in swimming pool water. Wastewater fluorescence has been

64 previously successfully investigated for detecting cross-connections between drinking

65 and recycled water systems (Hambly et al., 2010a,b). The authors reported promising role

66 of peak $T_{1}\left(\lambda_{\text {ex/em }}=300 / 350 \mathrm{~nm}\right)$ in distinguishing recycled water samples from potable

67 water samples (Hambly et al., 2010a). Moreover, combination of peak $\mathrm{T}_{1}$ and $\mathrm{C}_{1}\left(\lambda_{\text {ex/em }}=\right.$

68 325/426 nm) was able to further separate recycled water samples at various treatment 
Submitted to: Water Research

69 stages (Hambly et al., 2010b). In our study, the obtained fluorescence Excitation-

70 Emission Matrices (EEM’s) of swimming pool organic matter were evaluated by parallel

71 factor analysis (PARAFAC) modeling which delivered information on both qualitative

72 and quantitative aspects of the obtained fluorescence signal.

2. MATERIALS AND METHODS

\section{$76 \quad$ 2.1. Sampling and storage}

77 Two swimming pools at the Gladsaxe Sport Centre (Søborg, Gladsaxe council, Denmark)

78 were sampled during this study. One was a full length cold water pool $\left(2700 \mathrm{~m}^{3}\right)$ and the

79 other a smaller warm water basin $\left(50 \mathrm{~m}^{3}\right)$. Each pool has a separate water treatment

80 system. To minimize the adverse effect of chlorine on human skin, sodium chloride is

81 normally added to the water. A sodium chloride concentration of about $0.4 \%$ is

82 maintained in both basins. Water temperature is maintained in range of $26-27^{\circ} \mathrm{C}$ and 31 -

$8334{ }^{\circ} \mathrm{C}$ in the cold water and warm water basin, respectively. The $\mathrm{pH}$ was 7.4 in both

84 pools. The warm water pool had a 13-time higher number of guests per $\mathrm{m}^{3}$ than the cold

85 water pool, which corresponded to 4.6 and 0.35 persons $/ \mathrm{m}^{3} /$ day, respectively (Table 1).

86 A set-up of the water recirculation in the two systems is shown in Fig. 2. This

87 set-up was similar for both systems; therefore it is shown as one. In this set-up, only

88 elements of interest are shown. Both pool treatment systems contained coarse filtration

89 and sand filtration. Moreover, the warm water pool system contained side stream

90 activated carbon filtration and side stream UV treatment (these two stages were not in

91 operation during the experiment). Chlorine is produced from electrolysis of sodium 
Submitted to: Water Research

92 chloride. This is an in-line and an on-site production and dosage in the warm water pool

93 system and in the cold water system, respectively. In both systems, the water is

94 recirculated and about 3 to5 $\mathrm{m}^{3}$ of water is added per day. The filter beds had been

95 working for in the cold and warm water pool, respectively, and both were backwashed a

96 week before the study period.

97 During the experiment, samples were taken from a variety of sites to minimize

98 sampling error and generate a representative set of samples. All sampling sites for both

99 pool systems are marked in Fig. 1. For the cold water basin system, the sampling sites

100 were as follows: directly in the pool (site 1), pipe collecting water from the basin, before

101 the equalizing tank and sand filters (site 2), and a small pipe at the analytic board (site 3).

102 For the warm water pool, samples were taken directly from the pool (site 4), the

103 equalizing container collecting water from the basin (site 5) and a pipe at the analytic

104 board (site 6).

105 The difference between sampling sites between the two systems (sites 2 and 4) was

106 caused by their accessibility in terms of sampling and applying water quality sensors.

107 In the first series of the experiment, water quality was monitored for 5 days (3 days site 2

108 only and 2 days sites 1 and 3-6) within the opening hours (7-21 on weekdays and 8-15 on

109 weekend days) of the sport centre so the daily variability in fluorescence could be

110 assessed. Conductivity was measured on site with Hach HQ 14d meter (Hach Co., USA).

111 For fluorescence, absorbance, adsorbable organic halogens (AOX), and non-volatile

112 organic carbon (NVOC) analyses, water samples were collected in acid washed and

113 precombusted $\left(550^{\circ} \mathrm{C}\right) 40 \mathrm{ml}$ glass vials with Teflon-lined silicone caps. $100 \mu \mathrm{l}$ of

$114 \mathrm{Na}_{2} \mathrm{~S}_{2} \mathrm{O}_{3}$ solution (concentration of $5 \mathrm{~g} / \mathrm{l}$ ) was added to every sample to bind free chlorine 
Submitted to: Water Research

115 and stop further reaction with organic matter during storage (Johnstone and Miller, 2009).

116 Before sampling this preservation method had been evaluated for its effects on organic

117 matter fluorescence. No adverse effects were seen (Supplementary Information, SI -1.).

118 The collected samples were kept refrigerated at $4{ }^{\circ} \mathrm{C}$, transported to the laboratory and

119 analyzed within 3 days for NVOC and absorbance/fluorescence, and within 2 weeks for

120 AOX.

121

\section{2.2. Wastewater experiment}

123 In addition to the pool sampling a laboratory experiment with wastewater additions was

124 carried out. Raw municipal wastewater has been applied in the experiments as the source

125 of domestic waste including fractions released directly from human bodies thus

126 equivalent of anthropogenic organic matter in swimming pools (saliva, sweat, skin, hair,

127 urine, faeces etc.). A $5 \mathrm{~L}$ swimming pool water sample was taken from the warm-water

128 basin. The sample was kept refrigerated $\left(4^{\circ} \mathrm{C}\right)$ and used in the experiment on the

129 following day. Before starting the experiment the pool water was spiked with sodium

130 hypochlorite solution to re-establish in situ chlorine concentrations of $1.2 \mathrm{mg} / \mathrm{L}$ free $\mathrm{Cl}_{2}$.

131 The wastewater used in the experiment was raw sewage from a municipal wastewater

132 treatment plant serving 135,000 persons (Lundtofte, Kgs. Lyngby, Denmark). The

133 wastewater is mainly of residential origin, only $8-10 \%$ is industrial wastewater. It was

134 filtered through a 1.6- $\mu \mathrm{m}$ pore size glass fiber filter before use. The characteristics of the

135 water are shown in Table 2. The analyses were performed by a commercial laboratory

136 (Miljoelaboratoriet I/S, Glostrup, Denmark) except the NVOC analyses which were

137 carried out at DTU Environment (Kgs. Lyngby, Denmark). Total and combined chlorine 
Submitted to: Water Research

138 concentrations were measured by the DPD ( $N, N$-diethyl-p-phenylenediamine)

139 colorimetric method in a Allcon Test spectrophotometer (APHA, 2005).

$141 \quad$ 2.3. Analyses

142 In total, 103 samples of swimming pool water have been analyzed for fluorescence EEM

143 and NVOC to gain an understanding of how the fluorescence signal of pool organic

144 matter varies in intensity and characteristics throughout the day.

146 2.3.1. NVOC

147 NVOC was measured using a Shimadzu TOC-V WP analyzer with ASI_V autosampler.

148 The analyzer uses sodium persulfate solution, UV radiation and a temperature of $80^{\circ} \mathrm{C}$ to

149 oxidize organic carbon. A 10-fold auto-dilution was used for analysing swimming pool

150 water samples which had been previously found to show better reproducibility for

151 samples containing chloride ions (data not shown). For wastewater analysis, a manual

152 dilution of wastewater was prepared before analysis without further auto-dilution.

153

154 2.3.2. Fluorescence EEM with PARAFAC analysis

155 Fluorescence was measured in a 1- cm cuvette using a Varian Cary Eclipse Fluorescence

156 Spectrophotometer. Wavelength range for excitation spectra was 240-450 nm while for

157 emission 300-600 nm, with 5-nm and 2-nm steps, respectively. Excitation and emission

158 slit widths were set to $5 \mathrm{~nm}$ and photomultiplier tube voltage to 1000v. The excitation and

159 emission spectra measured from each sample were combined to create excitation

160 emission matrices (EEMs). In such obtained EEMs both excitation and emission 
Submitted to: Water Research

161 wavelengths were corrected using Rhodamine B and a ground quartz diffuser,

162 respectively. Sample inner filter effects were also corrected using absorption

163 measurements. Absorption measurements were performed on Varian Cary 50 Bio UV-

164 visible Spectrophotometer in a $1 \mathrm{~cm}$ quartz cuvette and UV-visible spectra recorded from

165240 to $700 \mathrm{~nm}$ with $0.5 \mathrm{~nm}$ slit. The correction was followed by Raman calibration

166 according to (Lawaetz and Stedmon, 2009). The calibrated and corrected fluorescence

167 data were then modeled using the DOMFluor Toolbox in Matlab ${ }^{\circledR}$ according to the

168 procedure recommended in (Stedmon and Bro, 2008). The number of fluorescence

169 components was found by a validation method including split half and residual analysis.

170 Short term changes in organic matter fluorescence immediately after addition to

171 chlorinated water were monitored by measuring 20 successive EEMs within 160 minutes

172 (repeated measurements without refilling the cuvette). A blank sample where swimming

173 pool water was replaced by MilliQ water was also measured.

175 2.3.3. AOX

176 AOX concentration was measured using a rapid analysis test kit from Hach-Lange

177 (LCK391) which is based on the same pre-treatment principle as the standard method

178 (ISO Standard, 2004) but with wet-oxidation of the carbon disc and photometric

179 determination of halogen ions $\left(\mathrm{Cl}^{-}\right)$.

\section{$181 \quad 2.4$. Detection limit}

182 Detection limits were calculated using a method based on $t$-distribution test (Harris, 183 2003). This method generates a detection limit that has a $99 \%$ chance to be greater than 
Submitted to: Water Research

184 the blank. Fluorescence EEMs of a blank sample which was swimming pool water

185 collected the day before the experiment was performed. A sample close to the DL (0.75

$186 \%$ wastewater addition) was generated and measured 7 times. In addition a series of

187 wastewater additions to swimming pool water were made in the concentration range of 0-

$1882 \%$ and their fluorescence measured. Fluorescence intensity of wastewater-like peaks,

189 found during PARAFAC modeling were used as signal response for calculations. The

190 signal detection limit was calculated according to equation 1 . The concentration detection

191 limit was calculated using the obtained calibration curve.

192

$193 \quad \mathrm{yDL}=\mathrm{yblank}+\mathrm{t} * \mathrm{~s}$

194

195 yDL - signal detection limit

196 yblank - fluorescence intensity for wastewater component in blank sample (average

197 value)

$198 \mathrm{t}$ - a value from $t$-distributuion test (equal to 3.14 for 7 measurements)

199 s - standard deviation of $0.75 \%$ wastewater sample (fluorescence intensity of

200 wastewater-like peak in the sample).

201

202

3. RESULTS AND DISCUSSION

203

204 3.1. PARAFAC components

205 Kinetics study of fluorescence in swimming pool water with wastewater addition showed

206 that all components were quite stable within the measurement time (160 minutes) 
Submitted to: Water Research

207 (Supplementary Information, SI - 2). Comparison of the EEMs of swimming pool water 208 with and without wastewater addition showed that swimming pool water exhibited very

209 low fluorescence. Consequently, the fluorescence spectrum of a swimming pool with

210 wastewater added is clearly dominated by the wastewater organic matter fluorescence

211 (Fig. 2). PARAFAC modeling of the swimming pool samples, including samples with

212 and without wastewater addition revealed that the fluorescence of organic matter in

213 swimming pools could be characterized by five different fractions (Table 3 and Figure 3).

214 There are no earlier studies of swimming pool water organic matter fluorescence to which

215 to compare these data directly. However, the swimming pool water spectrum resembled

216 the EEM of recycled water subjected to deep bed sand filtration, ultraviolet disinfection

217 and super-chlorination which has been reported by Halby et al. (2010b). The swimming

218 pool water organic matter fluorescence signals resembled those seen in natural waters.

219 The broad and long wavelength peaks of component 1 have also been found in a variety

220 of contrasting environments and it is thought to represent terrestrial material. Its presence

221 in the wastewater is likely due to surface run off (drainage) being present. Component 2

222 had a protein-like fluorescence. This type of fluorescence signals is often associated with

223 microbial activity found in many surface waters and associated with either biological

224 productivity or sewage contamination and referred to as the T peak, or protein-like peak

225 (Coble, 1996; Baker et al., 2004; Coble, 2007; Cumberland and Baker, 2007).

226 Component 3 is a ubiquitous fluorescence signal known as C-peak, found in almost all

227 types of waters, including surface, ground and marine waters (Coble 1996). However,

228 additional horizontal peaks in this EEM region, originating from optical brighteners have

229 been reported (Henderson et al., 2009 and references therein). These peaks are 
Submitted to: Water Research

230 characterized by excitation maxima at 375, 350 and $330 \mathrm{~nm}$, and emission maxima at

231 410-450 nm. Therefore, they can overlap with the humic-like peak C. Beside their

232 industrial applications (e.g. paper brightening), optical brightening agents are commonly

233 used in household detergents and thus can be found worldwide in sewage and sewage-

234 contaminated waters (Takahashi and Kawamura, 2007).

235 Component 4 resembles the previously identified M-peak. Originally, it was associated

236 with surface water productivity (Coble, 1996) but then it was found to be more of a

237 ubiquitous component (Coble, 2007). Component 5 exhibited a shape and form similar to

238 the protein-like peak but both its emission and excitation maxima were shifted towards

239 longer wavelengths.

241 3.2. Variation of fluorescence in swimming pool water samples

242 Among the fractions, component 5 was specific to swimming pool water and components

2431 and 3 were specific to wastewater. Components 2 and 4 were present in both water

244 types, however, at much higher concentrations than in wastewater (Fig.4).

245

246 3.3. Correlation of fluorescence components with wastewater addition

247 Components 1-4 showed strong correlation with wastewater concentration $\left(\mathrm{R}^{2} 0.985\right.$;

$248 \quad 0.989,0.987$ and 0.995, respectively) (Fig. 5). The corresponding $\mathrm{R}^{2}$ values for the fixed

249 wavelength pairs (without PARAFAC) were close and equaled 0.991; 0.986; 0.989 and

$250 \quad 0.993$ (data not shown).

251 The best linear relationship between wastewater concentration and fluorescence was

252 found for component 4. Components 1 and 3 have fluorescence maxima in excitation- 
Submitted to: Water Research

253 emission regions associated with humic substances content (Stedmon et al., 2003). As

254 they were found to be correlated with the wastewater concentration, they were likely

255 associated with wastewater humic matter. More specifically, component 1 represents

256 terrestrial fraction of wastewater organic matter, and component 3 was associated with

257 humic-like C-peak. Component 2 (protein-like) is characteristic for sewage contaminated

258 waters and has been previously found to be correlated with sewage content in the water

259 (Baker, 2001). Component 4 has been previously associated with phytoplankton or

260 microbial productivity. In our experiment this peak was assumed to be associated with

261 wastewater microbial activity. Within the five fluorophores only component 5 was not

262 correlated with wastewater concentration, hence associated with swimming pool organic

263 matter. Considering component 5's “position” in the EEM, which is between protein-like

264 and humic-like regions, this component is most likely a combination of swimming pool

265 microbial activity products and swimming pool humic-like substances.

266 Fluorescence intensity of component 5 exhibited an average intensity of 0.047 R.U. with

267 standard deviation of 0.002 R.U.

268

269 3.4. Daily variability of fluorescence in the swimming pool

270 The possibility of using components 1-4 for monitoring anthropogenic contamination in

271 swimming pools was tested on fluorescence daily variation data. Compared to the cold

272 water pool the warm water basin was supposed to contain more contamination due to

273 smaller volume and high number of visitors. An example of daily variation of

274 fluorescence in the warm water basin is shown in Fig. 6. 
Submitted to: Water Research

For the warm water swimming pool, among the four wastewater-like peaks

276 component 3 shows the biggest increase through the day (almost doubled on both

277 sampling days). Similarly, component 4 almost doubled through both sampling days.

278 However, component 4 fluorescence exceeded the wastewater detection limit for two

279 samples only, whereas component 3 was above the detection limit for the both entire

280 days. Component 5, a swimming pool organic matter-like peak, showed some variation

281 but no systematic trend during the day. Fluorescence of components 1 and 2 was below

282 the wastewater detection limit through the whole sampling period.

283

284 3.5. Correlation between fluorescence, NVOC, AOX and combined chlorine

285 For the warm water pool, the NVOC content was in range of 2.2-2.8 $\mathrm{mg} / \mathrm{L}$ on the first

286 sampling day, and higher (range 2.5- $3.2 \mathrm{mg} \mathrm{C/L}$ ) on the second sampling day, and

287 increased through the day. The increase in NVOC was caused by input of two organic

288 fractions, assigned as components 3 and 5 which were correlated with NVOC (Fig.7a).

289 The $\mathrm{R}^{2}$ values of the correlations indicate level of significance of almost $99.9 \%$ and

290 higher than $99.9 \%$ for components 5 and 3, respectively.

291 The material released from bodies of bathers in swimming pools contains both

292 organic matter and ammonia and can react with chlorine. The latter reaction forms

293 chloramines. Both chlorinated and non-chlorinated organic matter can be detected as total

294 or non-volatile organic carbon. Therefore, in this study the concentration of combined

295 chlorine in the swimming pools was correlated with NVOC $\left(\mathrm{R}^{2}\right.$ of 0.626 , data not

296 shown). Consequently, a correlation between fluorescence component 3 and 5 and 
Submitted to: Water Research

297 combined chlorine concentration in the warm water pool was found (Fig.7b), with levels

298 of significance higher than $95 \%$ for both components.

299 High concentration of disinfection by-product in the swimming pool water, showed by

300 chloramines, was also confirmed by the AOX content which was in range of 1.73-2.03

$301 \mathrm{mg} / \mathrm{L}$ for the warm water pool. Negative correlations between AOX and NVOC, and

302 AOX and fluorescence of components 3 and 4 were also observed (Fig. SI-5).

303

304 3.6. Cold water pool

305 For the cold water pool, almost all the wastewater-like components showed fluorescence

306 below the wastewater detection limit. On the both sampling days, only one sample

307 slightly exceeded the detection limit (data not shown). The NVOC values for the cold

308 water pool were constant (1.8 - $1.9 \mathrm{mg} \mathrm{C} / \mathrm{L}$ on both measurement days). Therefore, no

309 correlation between fluorescence and NVOC, and fluorescence and combined chlorine

310 was observed in the cold water pool. Combined chlorine concentration was in range of

311 0.4-0.6 mg/L, and AOX content varied from 1.0 to $1.26 \mathrm{mg} / \mathrm{L}$, whereas THM

312 concentration was $23 \mu \mathrm{g} / \mathrm{L}$.

313

314 3.7. Monitoring organic matter loading and accumulation in swimming pool water

315 The trend in component 3 observed for the warm water pool represents organic loading to

316 the pool which can be direct release of organic matter to the pool and/or a product of its

317 initial oxidation. This component is stable and accumulates during the day but becomes

318 oxidized during the night when the organic loading to the pool has stopped (i.e. there are

319 no guests in the pool). No similar accumulation was observed in the cold water 
Submitted to: Water Research

320 swimming pool. Most probably, this is due to the high number of bathers in the warm

321 water pool (Table 1). Moreover, a higher temperature in the warm water pool (31-34 and

$32227^{\circ} \mathrm{C}$ in the warm and the cold water pool, respectively) could both promote release of

323 organic substances from the bather's skin and stimulate the production rate of the

324 oxidized fraction of component 3. The higher organic matter release and oxidation extent

325 is confirmed by higher NVOC, THM and AOX concentration in the warm water pool

326 (ref. sections 3.5. and 2.6., and Table 1). Similarly, Glauner et al. (2005) found that total

327 organic carbon and THM concentration correlated well with the overall bather number in

328 a pool.

329 Component 5 consists of substances permanently present in swimming pool water, which

330 most likely can be associated with products of oxidation reactions in the swimming pool

331 water. A relatively high concentration of chlorine in the investigated water excludes

332 significant microbial production that had been previously related to this fluorescence

333 region (Henderson et al., 2009). Therefore, component 5 is likely produced in chemical

334 rather than microbial reactions proceeding in the swimming pool water.

\section{$336 \quad 3.8$. Wastewater detection limit}

337 The detection limits of wastewater in the swimming water were calculated for all the 338 wastewater components (Table 4). It shows that the lowest detection limit was found for

339 component 4 and equaled $0.2 \% \mathrm{v} / \mathrm{v}$ of wastewater. The highest detection limit has been

340 obtained for component 1 and it was four times higher than for component 4 . The

341 detection limit for components 3 was $0.6 \% \mathrm{v} / \mathrm{v}$ of wastewater, which for this

342 experimental set up corresponded to $0.13 \mathrm{mg} \mathrm{C} \mathrm{/L.} \mathrm{The} \mathrm{five} \mathrm{facts:} \mathrm{i)} \mathrm{specificity} \mathrm{of}$ 
Submitted to: Water Research

343 component 3 to wastewater, ii) its stability in chlorinated water, iii) the increase in

344 fluorescence of this component through the opening hours, iv) its correlation with NVOC

345 and combined chlorine, and v) its sensitivity to wastewater additions, confirms its

346 usefulness for anthropogenic matter detection. This means that among the three

347 wastewater components, component 3 was found to contain a fraction that might be

348 released to water by the swimming pool guests. Therefore, the excitation and emission

349 maxima of component 3 are recommended for monitoring of organic loading in

350 swimming pool water. The fact that a humic-like fluorescence peak is a waste indicator in

351 swimming pool water, is a novel finding. Previous works on detecting waste

352 contamination in surface and potable waters showed that the protein-like peaks are the

353 best waste indicators (Henderson et al., 2009 and references therein) and that peak C

354 plays a supplementary role (Hambly et al., 2010a,b). However, in the highly oxidative

355 environment of swimming pool water, tryptophan-like material does not persist. Most

356 likely, the suite of reactions on the organic matter released in the pools does occur and

357 one of the reaction products has a humic-like fluorescence signal, similar to what is found

358 in many natural waters.

359

360 4. CONCLUSIONS

361

362 - Organic matter fluorescence has a potential for monitoring swimming pool water

363 quality.

364 - Among the two investigated pools, only the warm water pool exhibited waste

365 contamination. 
Submitted to: Water Research

366

367

368

369

370

371

372

373

\section{Acknowledgements}

375 Jørgen Vienberg, Tom Østmar, and other staff at the Gladsaxe Sport Center, for allowing

376 access to the swimming pools and helping with the sampling. Sinh Hy Nguyen and Peter

377 Kofoed for their technical assistance. Henrik R. Andersen for his helpful comments. This

378 research was supported by the Danish Agency for Spatial and Environmental Planning,

379 Ministry of the Environment (Ref. BLS-403-00043 Aqua Fingerprint).

381 References

382 APHA, AWWA, WEF (2005), Standard methods for the examination of water and 383 wastewater, 21st ed.

384 Baker, A. (2001) Fluorescence excitation-emission matrix characterization of some

385 sewage-impacted rivers. Environmental Science and Technology 35, 948-953.

386 Baker, A., Ward, D., Lieten, S. H., Pereira, R., Simpson, E. C. and Slater, M. (2004)

387 Measurement of protein-like fluorescence in river and waste water using a handheld 388 spectrophotometer. Water Research 38, 2934-2938. 
Submitted to: Water Research

389 Coble, P. G. (1996) Characterization of marine and terrestrial DOM in seawater using

390 excitation-emission matrix spectroscopy. Marine Chemistry 51, 325-346.

391 Coble, P. G., Green, S. A., Blough, N. V. and Gagosian, R. B. (1990) Characterization of

392 dissolved organic matter in the Black Sea by fluorescence spectroscopy. Nature 348, 432-

393435.

394 Coble, P.G. (2007) Marine optical biogeochemistry: The chemistry of ocean color.

395 Chemical Reviews 107, 402-418.

396 Cumberland, S. A. and Baker, A. (2007) The freshwater dissolved organic matter

397 fluorescence-total organic carbon relationship. Hydrological Processes 21, 2093-2099.

398 Directive (2006) Directive 2006/7/EC of the European Parliament and of the Council of

39915 February 2006 concerning the management of bathing water quality and repealing

400 Directive 76/160/EEC.

401 DS/EN 1899-1 (1999). Water quality - Determination of biochemical oxygen demand

402 after n-days $\left(\mathrm{BOD}_{\mathrm{n}}\right)$ - Part1: Dilution and seeding method with allylthiourea addition.

403 DS 2255 (2001). Water quality - Enumeration of coliform bacteria and thermotolerant

404 coliform bacteria - Multiple-tube fermentation method (Most-Probable Number method).

405 DS 292 (1985). Water analysis - Total phosphorus - Photometric method.

406 DS/EN ISO 11905-1 (1997). Water quality - Determination of nitrogen - Part 1: method

407 using oxidative digestion with peroxodisulfate.

408 DS/EN ISO 6222 (2000). Water quality - Enumeration of culturable microorganisms -

409 Colony count by inoculation in a nutrient agar culture medium.

410 DS/ISO 15705 (2002). Water quality - Determination of chemical oxygen demand index

411 (ST-COD) - small-scale sealed-tube method. 
Submitted to: Water Research

412 Fabbricino, M. and Korshin, G.V. (2004) Probing the mechanisms of NOM chlorination

413 using fluorescence: formation of disinfection by-products in Alento River water. Water

414 Science and Technology: Water Supply 4, 227-233.

415 Glauner, T_, Waldmann, P., Frimmel, F. H., Zwiener, C. (2005) Swimming pool water-

416 fractionation and genotoxicological characterization of organic constituents. Water

$417 \quad$ Research 39, 4494-4502.

418 Harris, D.C. (2003) Quantitative Chemical Analysis, Sixth ed., W.H. Freeman and

419 Company, Michelle Russel Julet, New York, 726-727.

420 Hambly, A. C., Henderson, R. K., Baker, A., Stuetz, R. M. and Khan, S. J. (2010)

421 Fluorescence monitoring for cross-connection detection in water reuse systems:

422 Australian case studies. Water Science \& Technology 61(1), 155-162.

423 Hambly A. C, Henderson R. K, Storey M. V., Baker A, Stuetz R. M, and Khan S. J.

424 (2010) Fluorescence monitoring at a recycled water treatment plant and associated dual

425 distribution system--implications for cross-connection detection. Water Research 44(18), $426 \quad 5323-5333$.

427 Henderson, R. K., Baker, A., Murphy, K. R., Hambly, A., Stuetz, R. M. and Khan, S. J. 428 (2009) Fluorescence as a potential monitoring tool for recycled water systems: A review.

429 Water Research 43, 863-881.

430 ISO 9562 (2004) Water quality -- Determination of adsorbable organically bound

431 halogens (AOX).

432 Johnstone, D. W. and Miller, C. M. (2009) Fluorescence excitation-emission matrix

433 regional transformation and chlorine consumption to predict trihalomethane and

434 haloacetic acid formation. Environmental Engineering Science 26, 1163-1170. 
Submitted to: Water Research

435 Lawaetz, A. J. and Stedmon, C. A. (2009) Fluorescence intensity calibration using the

436 Raman scatter peak of water, Applied Spectroscopy 63, 936-940.

437 Lee, J., Ha, K.-T. and Zoh, K.-D. (2009) Characteristics of trihalomethane (THM)

438 production and associated health risk assessment in swimming pool waters treated with

439 different disinfection methods. Science of The Total Environment 407, 1990-1997.

440 Muller, C. L., Baker, A., Hutchinson, R., Fairchild, I. J. and Kidd, C. (2008) Analysis of

441 rainwater dissolved organic carbon compounds using fluorescence spectrophotometry.

442 Atmospheric Environment 42, 8036-8045.

443 Roccaro, P., Vagliasindi, F. G. A. and Korshin, G. V. (2009) Changes in NOM

444 fluorescence caused by chlorination and their associations with disinfection by-products

445 formation. Environmental Science and Technology 43, 724-729.

446 Stedmon, C. A., Markager, S. and Bro, R. (2003) Tracing dissolved organic matter in

447 aquatic environments using a new approach to fluorescence spectroscopy. Marine

448 Chemistry 82, 239-254.

449 Stedmon, C.A. and Bro, R. (2008) Characterizing dissolved organic matter fluorescence

450 with parallel factor analysis: a tutorial. Limnology and Oceanography: Methods 6, 572451579.

452 Takahashi M. and Kawamura, K (2007) Simple measurement of 4,4'-bis(2-sulfostyryl)-

453 biphenyl in river water by fluorescence analysis and its application as an indicator of

454 domestic wastewater contamination. Water, Air \& Soil Pollution 180, 39-49.

455 Uhl, W. and Hartmann, C. (2005) Disinfection by-products and microbial contamination

456 in the treatment of pool water with granular activated carbon. Water Science and

457 Technology 52, 71-76.

458 
Submitted to: Water Research

$459 \quad$ Figures

460

461 1. Set-up of the warm and cold water swimming pool systems. Sampling sites (described

462 in section 2.1.) are marked with numbers.

463 2. Example EEMs of the swimming pool water and wastewater samples - top row-

464 measured data, bottom row - PARAFAC model: (a) cold water pool sample, (b) warm

465 water pool sample with $0.75 \%$ addition of wastewater, (c) MQ water with $0.75 \%$ addition

466 of wastewater, (d) warm water pool sample.

467 3. EEMs of PARAFAC components (contour plots) found for the swimming pool water

468 (warm pool) and wastewater samples.

469 4. The fluorescence intensity of each of the five components (c1-c5): Milli Q water with

$470 \quad 0.75 \% \mathrm{v} / \mathrm{v}$ wastewater, swimming pool water (stored overnight at $4^{\circ} \mathrm{C}$ without addition of

$471 \mathrm{Na}_{2} \mathrm{~S}_{2} \mathrm{O}_{3}$ ) and swimming pool water with $0.75 \% \mathrm{v} / \mathrm{v}$ wastewater. Values presented are

472 averages of seven replicate measurements and the error bars represent one standard

473 deviation.

474 5. Correlation between fluorescence of the PARAFAC components (c1-c5) and

475 wastewater concentration in the swimming pool - wastewater samples.

476 6. En example of daily variation of the PARAFAC fluorescence components 1 to 5 (c1-

477 c5) in the warm water pool.

478 7. a) NVOC, b) combined chlorine vs. fluorescence of PARAFAC components 3 and 5

479 (c3 and c5) in samples collected from the warm water pool.

480 
Submitted to: Water Research

481 Table 1 - Charcateristics of the two investigated swimming pools.

\begin{tabular}{|c|c|c|c|}
\hline Factor & Unit & $\begin{array}{l}\text { WW, warm water pool. } \\
\text { Experimental period } \\
\text { (average from ref. } \\
\text { period in Gladsaxe } \\
\text { report in parenthesis) }\end{array}$ & $\begin{array}{l}\text { CW, cold water pool } \\
\text { Experimental period }\end{array}$ \\
\hline Volume of pool & $\mathrm{m}^{3}$ & 50 & 2700 \\
\hline Area of pool & $\mathrm{m}^{2}$ & 39 & 1050 \\
\hline Temperature & $\operatorname{deg} C$ & $31-34$ & 27 \\
\hline Turn over time & $\mathrm{h}$ & 0.5 & 5 \\
\hline Bathers per day & persons/d & 228 & $900-1000$ \\
\hline Person volumetric load & $\mathrm{p} / \mathrm{m}^{3} / \mathrm{d}$ & 4.6 & 0.35 \\
\hline Water addition/d & $\mathrm{m}^{3} / \mathrm{d}$ & $3-5$ & $3-5$ \\
\hline Chlorine conc. & $\mathrm{mg} \mathrm{Cl}_{2} / \mathrm{L}$ & 1.1 & 0.65 \\
\hline Filter area & $\mathrm{m}^{2}$ & $7-8$ & 21 \\
\hline Filter period (run time) & weeks & 1 & 1 \\
\hline pH & - & 7.4 & 7.4 \\
\hline Chlorine conc. & $\mathrm{mg} \mathrm{Cl} / \mathrm{L}$ & 1.1 & 0.65 \\
\hline Combined chlorine & $\mathrm{mg} \mathrm{Cl}_{2} / \mathrm{L}$ & $0.8-1.1$ & $0.4-0.6$ \\
\hline Pool THM & $\mu \mathrm{g} / \mathrm{L}$ & $32-50(41)$ & 23 \\
\hline Pool AOX & $\mathrm{mg} / \mathrm{L}$ & $1.7-2(2.1)$ & $1.0-1.3$ \\
\hline Pool NVOC & $\mathrm{mg} / \mathrm{L}$ & $2.5-2.9(3.5)$ & $1.8-1.9$ \\
\hline
\end{tabular}


Submitted to: Water Research

486 Table 2 - Characteristics of filtered and unfiltered wastewater used in the experiment.

\begin{tabular}{|c|c|c|c|c|}
\hline Parameter & Unfiltered WW & Filtered WW & Unit & Method/Standard \\
\hline BOD & 330 & 73 & $\mathrm{mg} \mathrm{O}_{2} / \mathrm{L}$ & DS/EN 1899-1 \\
\hline COD & $1.2 \mathrm{E}+03$ & 180 & $\mathrm{mg} \mathrm{O}_{2} / \mathrm{L}$ & DS/ISO 15705 \\
\hline Total nitrogen & 60 & 42 & $\mathrm{mg} \mathrm{N} / \mathrm{L}$ & DS/EN ISO 11905-1 \\
\hline Total phosphorus & 12 & 6.5 & mg P/L & DS 292 \\
\hline Coliform bacteria & $1.3 \mathrm{E}+07$ & & CFU/100 mL & DS 2255 \\
\hline $\begin{array}{l}\text { Thermotol. coliform } \\
\text { bacteria }\end{array}$ & $1.3 \mathrm{E}+07$ & & CFU/100 mL & DS 2255 \\
\hline $\mathrm{HPC}_{\text {yeast }} 22^{\circ} \mathrm{C}, 72 \mathrm{~h}$ & $1.5 \mathrm{E}+07$ & & $\mathrm{CFU} / \mathrm{mL}$ & DS/EN ISO 6222:2000 \\
\hline $\mathrm{HPC}_{\text {yeast }} 37^{\circ} \mathrm{C}, 48 \mathrm{~h}$ & $0.5 \mathrm{E}+07$ & & $\mathrm{CFU} / \mathrm{mL}$ & DS/EN ISO 6222:2000 \\
\hline NVOC & & 24.0 & $\mathrm{mg} \mathrm{C/L}$ & \\
\hline
\end{tabular}


Submitted to: Water Research

489 Table 3 - Excitation and emission maxima of PARAFAC components found for

490 swimming pool - wastewater samples.

\section{Component number Excitation wavelength, nm Emission wavelength, nm}

\begin{tabular}{lll}
\hline $\mathbf{1}$ & $260,<240,370$ & 520 \\
$\mathbf{2}$ & 280 & 330 \\
$\mathbf{3}$ & $<240,330$ & 420 \\
$\mathbf{4}$ & $<240$ & 370 \\
$\mathbf{5}$ & $<240,310$ & 360
\end{tabular}

491

492 
Submitted to: Water Research

493 Table 4 - Wastewater detection limits in the swimming pool water for the PARAFAC

494 components.

\begin{tabular}{lcccc} 
Detection limit, DL & c1 & c2 & c3 & c4 \\
\hline DL [\% WW] & 0.8 & 0.5 & 0.6 & 0.2
\end{tabular}

495

496 
Submitted to: Water Research

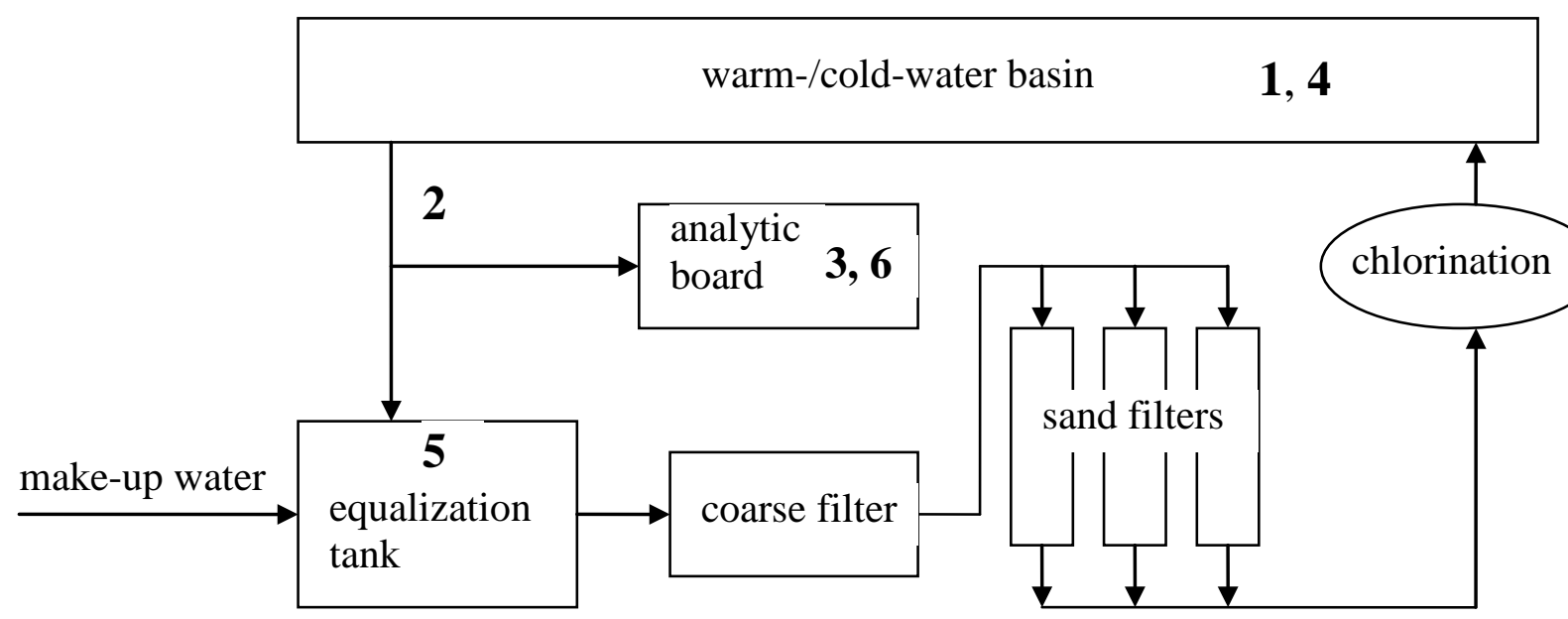

500

Fig. 1. 
Submitted to: Water Research

501
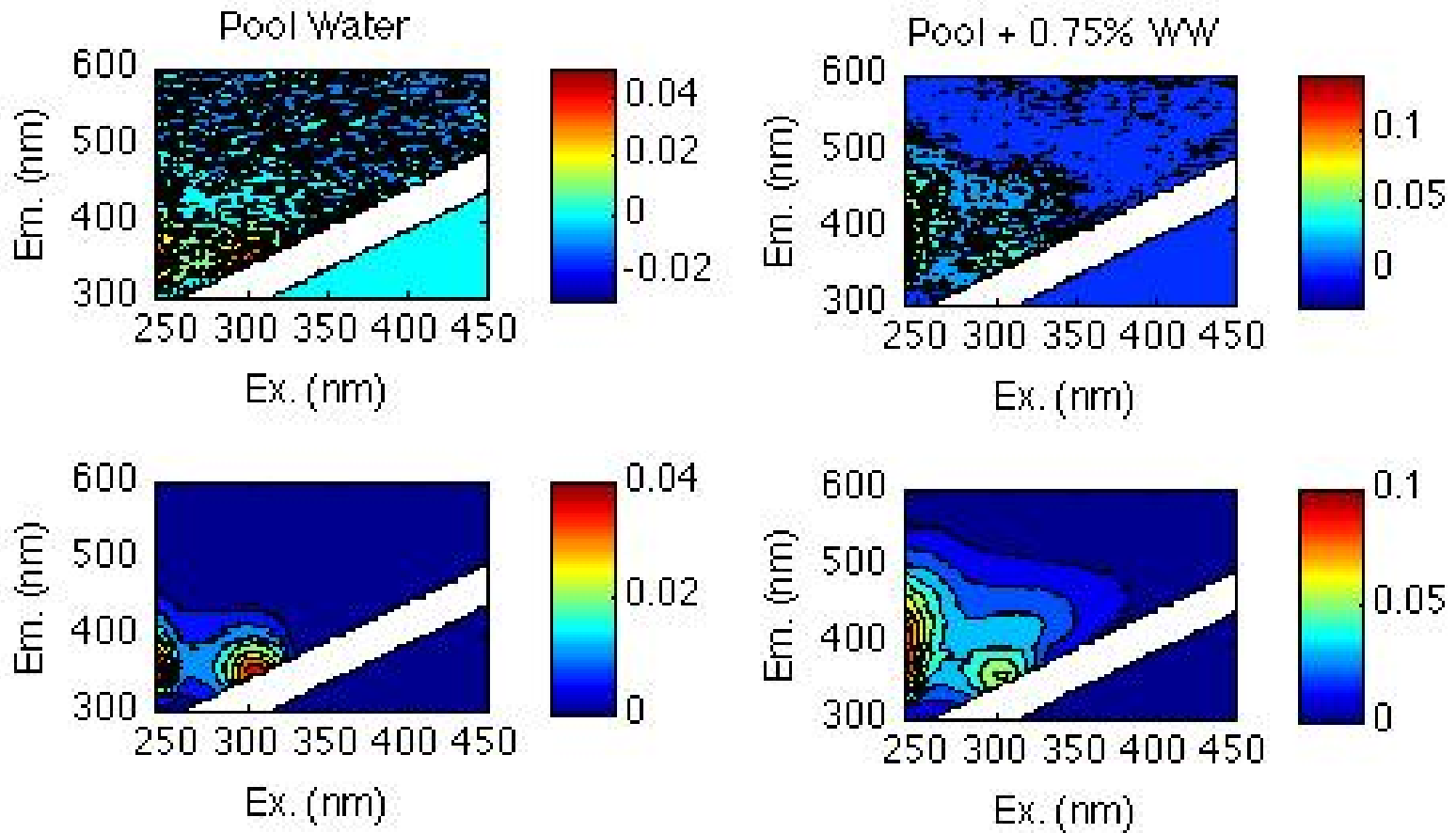

a)
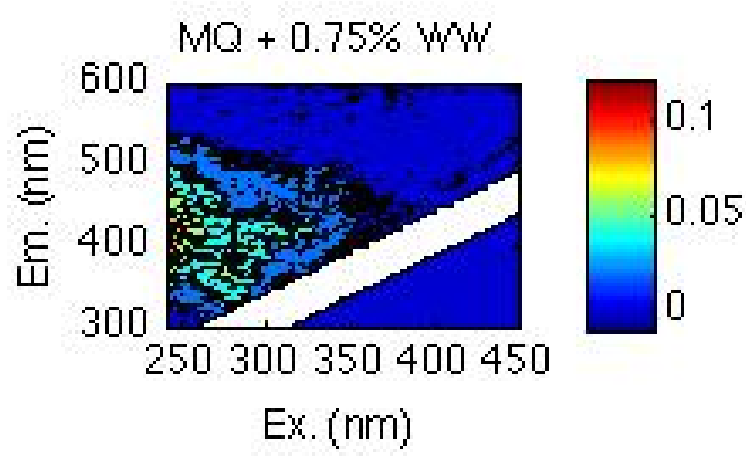

b)

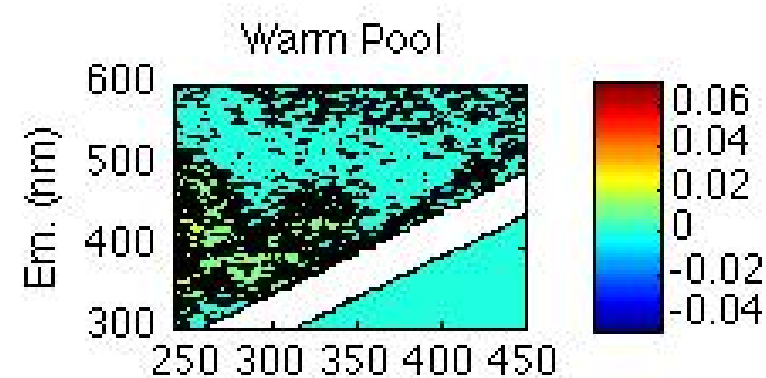

Ex. (nm)
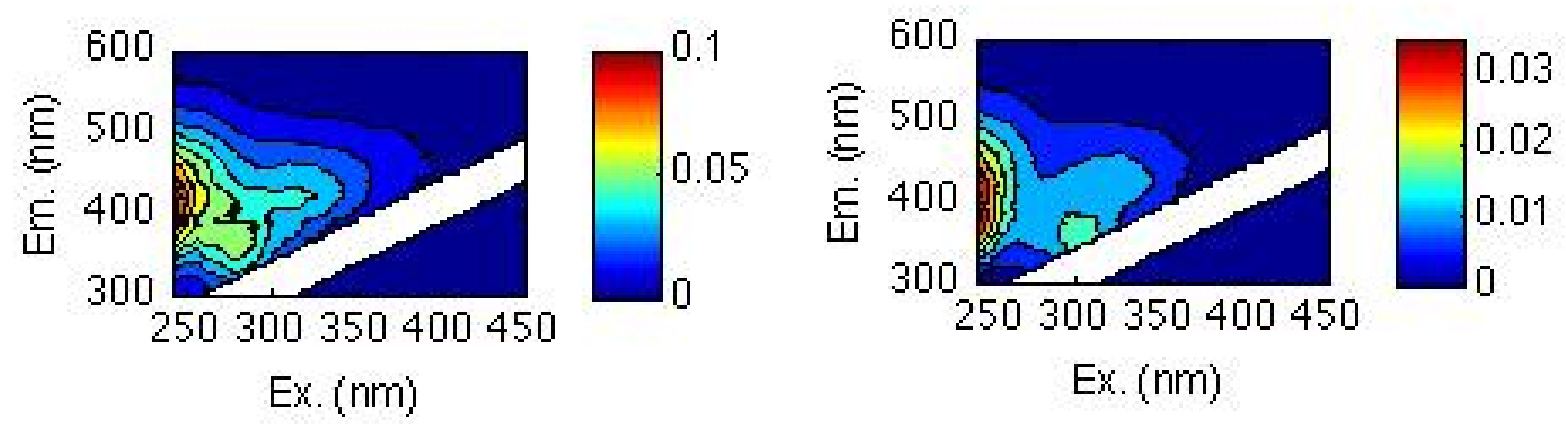

c)

d)

502

503

Fig. 2.

504 
Submitted to: Water Research

505
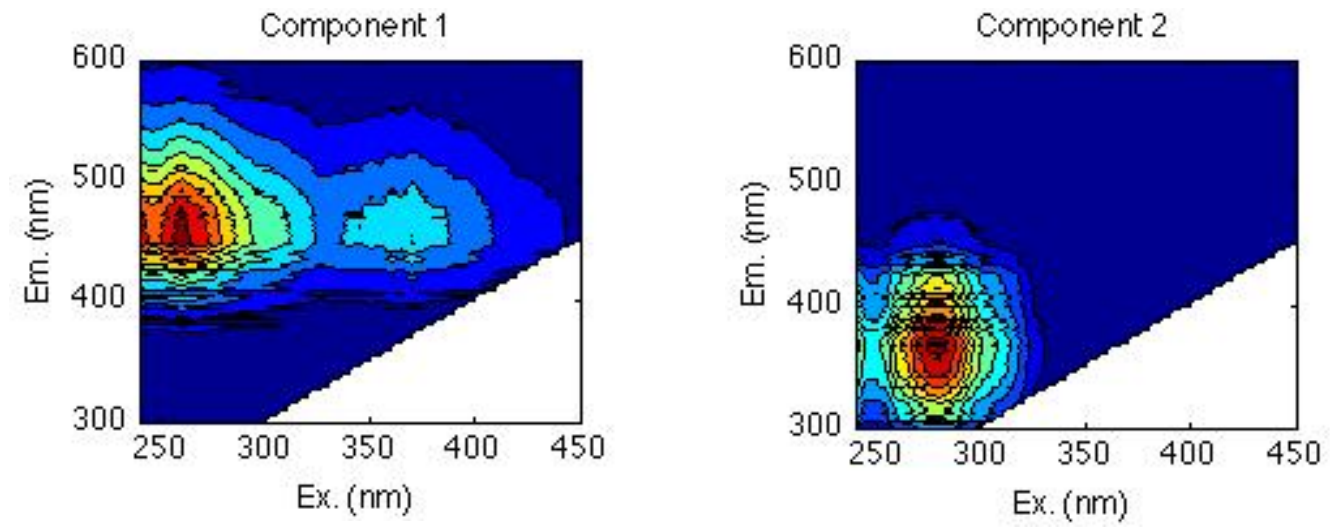

a)

b)
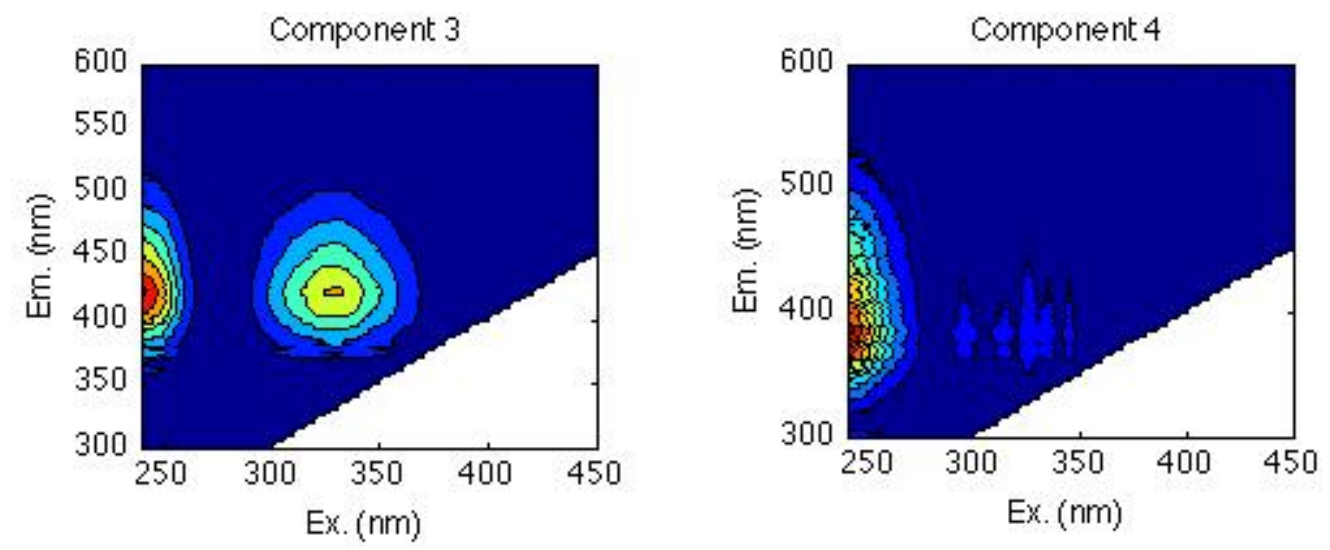

c)

d)

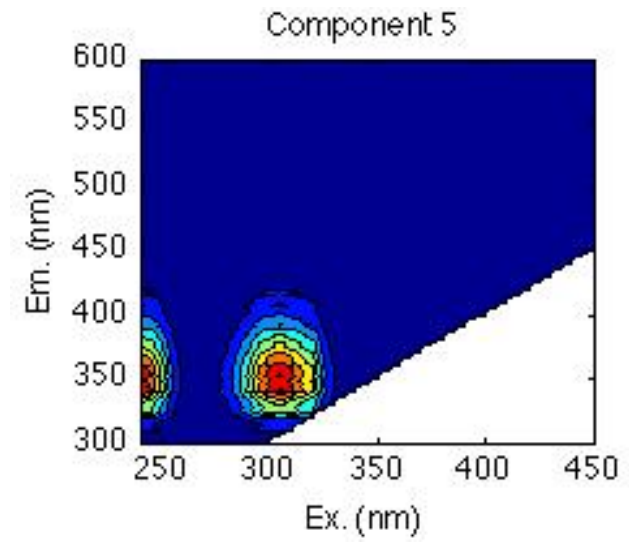

e)

506 Fig. 3.

507

508 
Submitted to: Water Research

509

510 
Submitted to: Water Research

511

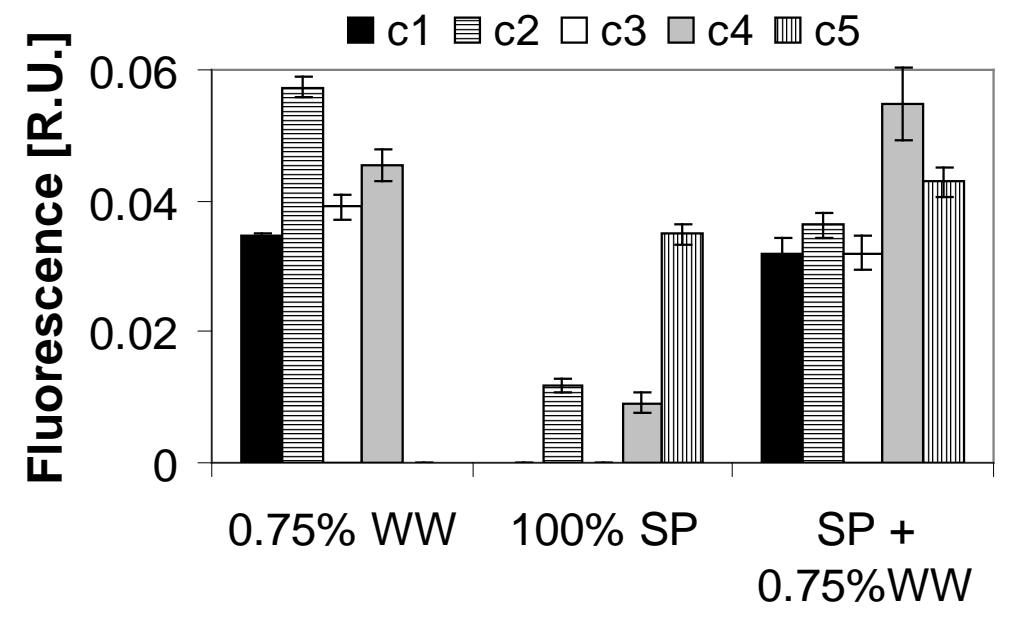

512

Sample type

513 Fig. 4.

514 
Submitted to: Water Research

515

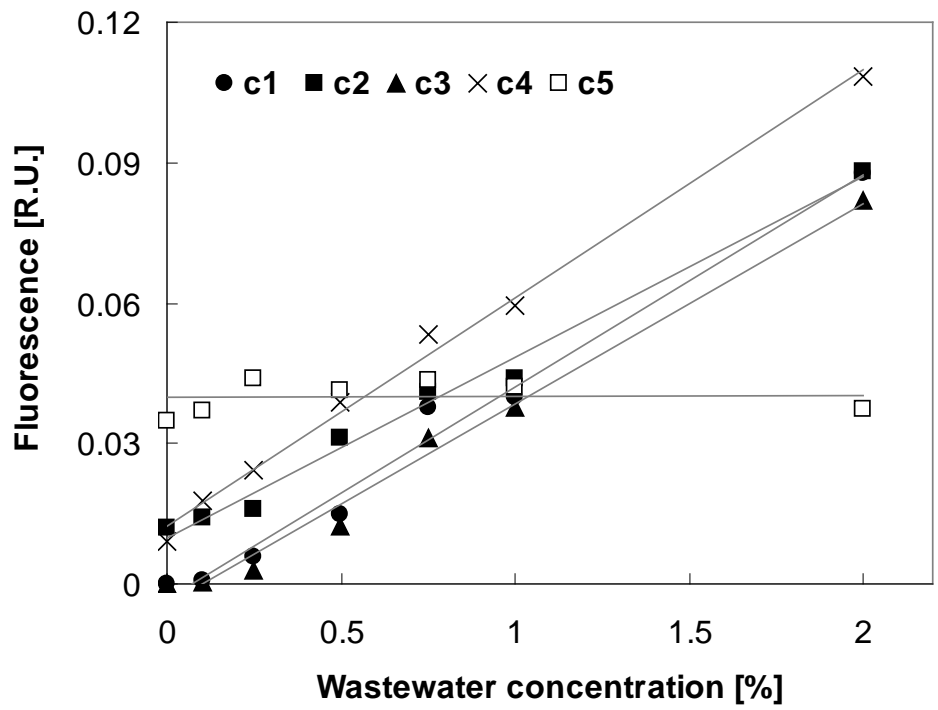

516

517

518 Fig. 5.

519 
Submitted to: Water Research

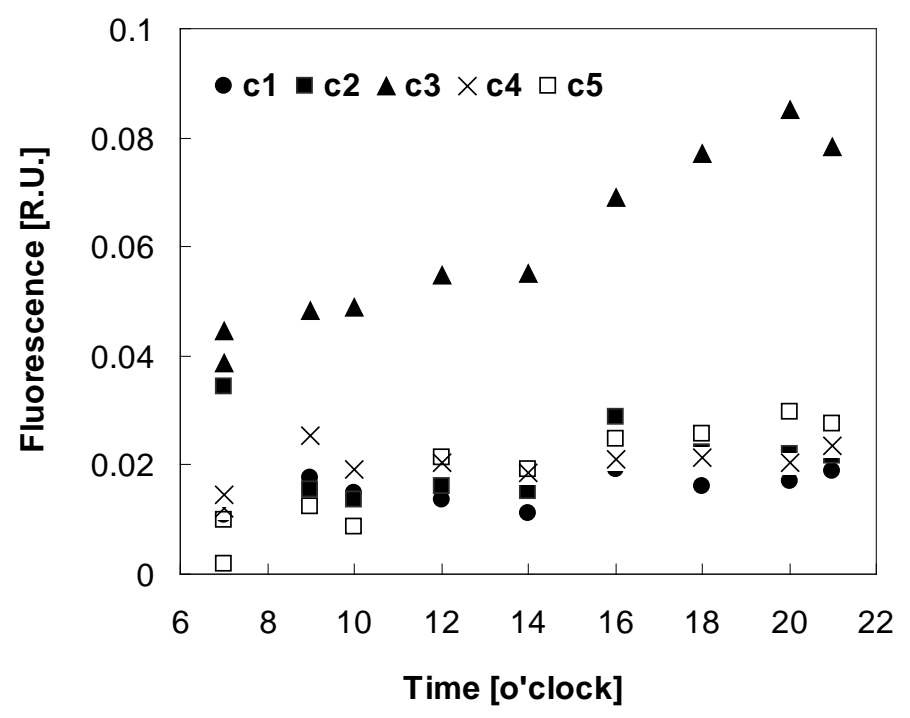

520

Fig. 6.

522 
Submitted to: Water Research

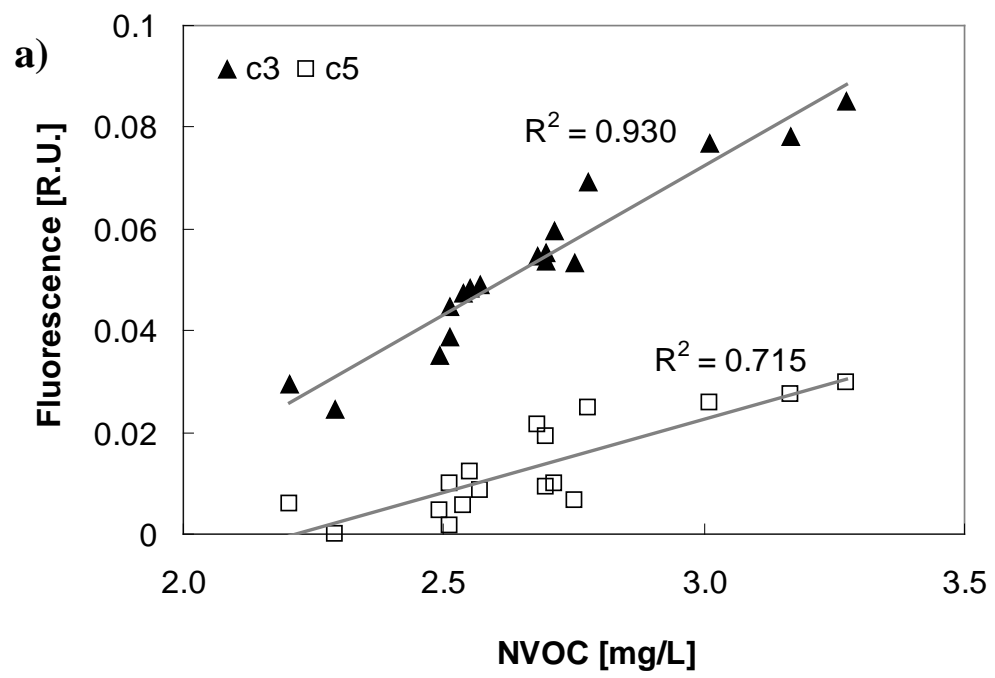

523

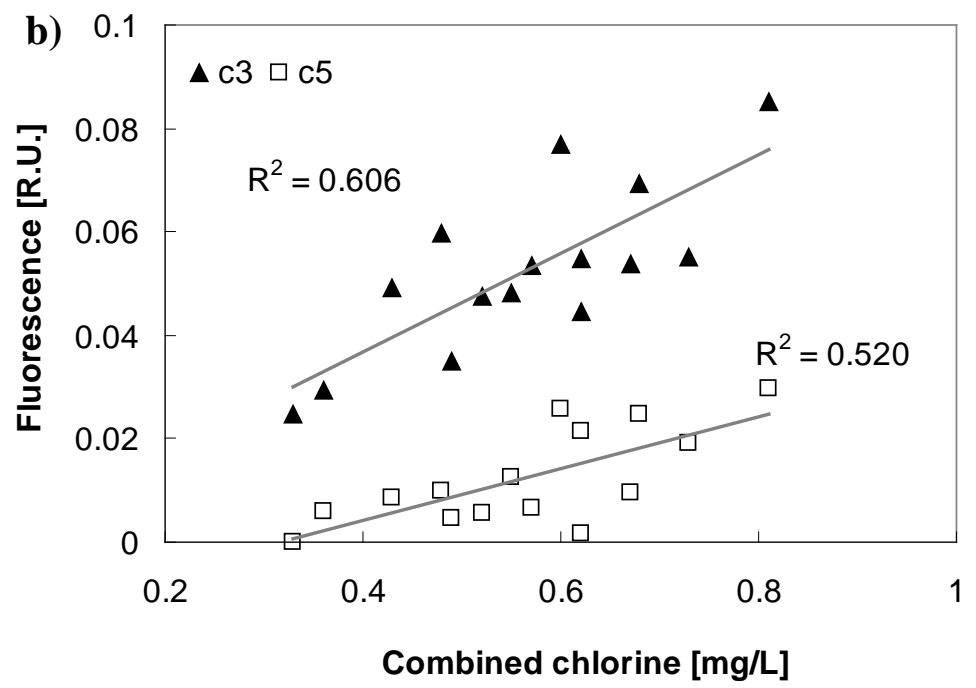

524

525 Fig. 7.

526 
Submitted to: Water Research

527 SI-1 - Tests on the effects of chlorination on organic matter fluorescence and the

528 ability of sulfite addition to stop further loss of fluorescence during storage.

\section{Introduction}

531 As part of the preparations for this study and small experiment was carried out to resolve

532 the effects on organic matter fluorescence of adding sulfite. As there was going to be a

533 delay 1-7 days between sampling and analysis where in principle the chlorine in the pool

534 water would continue to react wit the organic matter in the samples during storage. To

535 remove free chlorine and subsequently limit storage effects sulfite addition was tested.

\section{Method}

538 A large volume sample of tap water (Roskilde, Denmark) was taken for the experiment.

539 The control samples consisted of unamended tap water and the organic matter

540 fluorescence measured represents the natural organic matter in drinking water. Sodium

541 hypochlorite $(\mathrm{NaOCl})$ was added to a sub sample of tap water to create an analogy to

542 swimming pool water with a free chlorine concentration of $1 \mathrm{mg} / \mathrm{L} \mathrm{Cl}_{2}$. Tap water

543 dispensed into three $1 \mathrm{l}$ bottles. One left as control, the two others were filled with

544 chlorinated water. After half an hour sodium sulfite was added (30:1 molar excess of

545 sulfite to chlorine). A series of bottles were then filled and stored refrigerated.

546 Measurements were made at the start $(\mathrm{t}=0)$, after 24 hours $(\mathrm{t}=1)$ and after 7 days $(\mathrm{t}=3)$

\section{$548 \quad$ Results}


Submitted to: Water Research

549 From the EEMs presented in Figure SI-1 is it clear that the sulfite addition had limited if

550 any effects on the fluorescence. No substatial spectral changes are apparent. Comparing

551 the start samples one can see that the addition of chlorine redcued the overall

552 fluorescence intensity. The EEM of the start sample with sulfite has a slightly higher

553 fluorescence intensity than the chlorinated only sample revealing that between the

554 chlorine addition and the sulfite addition some fluorescence was lost. After one weeks

555 storage little change has occurred in the control and the sulfite amended sample where as

556 the chlorinated sample fluorescence has decreased. In order to se these changes better

557 selected excitation and emission spectra are plotted in Figure SI-2 and SI-3. From the

558 spectra in Figure SI-2 one can see that the control and sulfite amended samples are very

559 stable. The fluorescence signal in the chlorinated sample continues to fall during storage

560 as the chlorine reacts. Figure SI-3 compares the excitation spectra across treatments.

561

562 

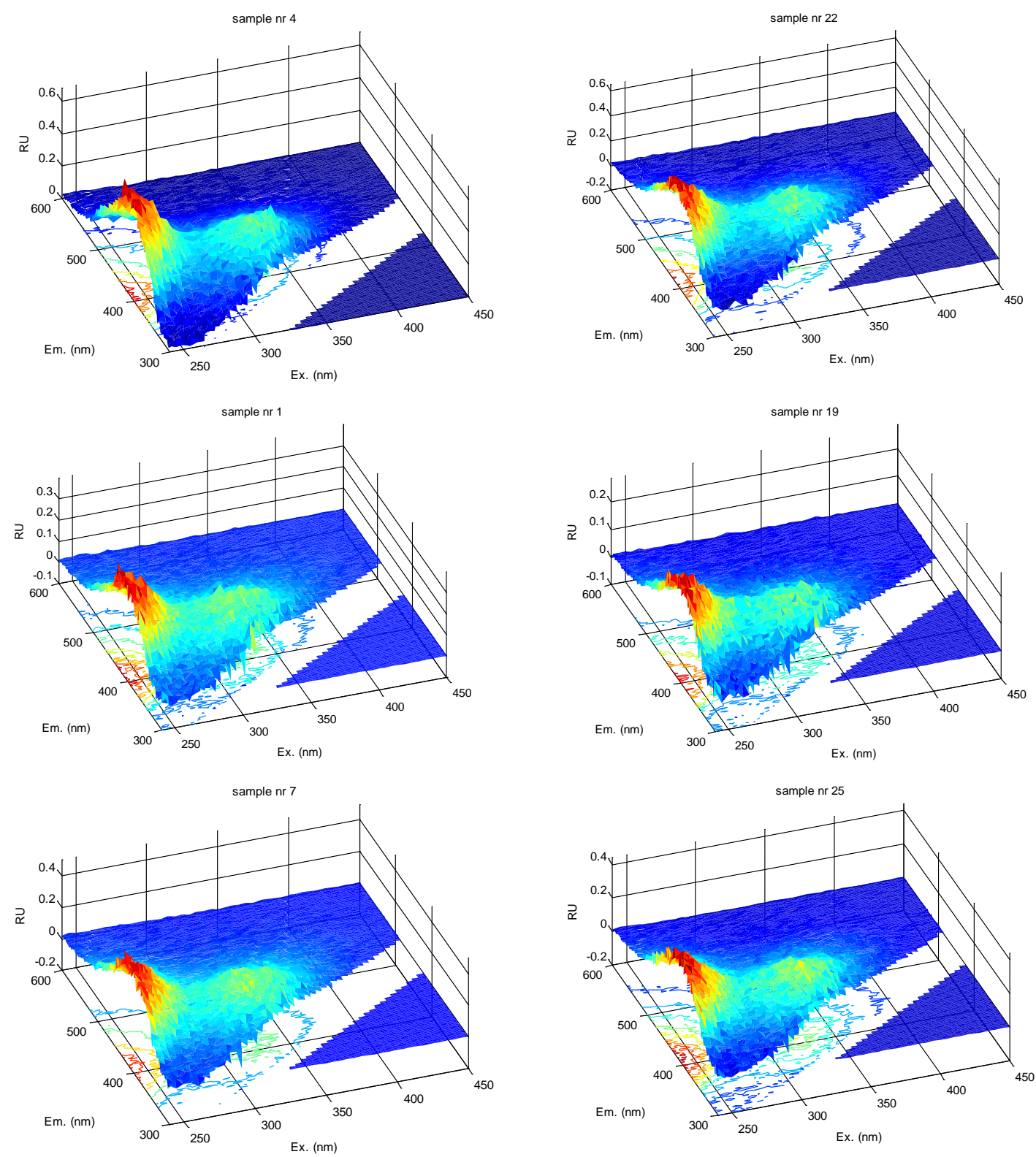

Figure SI-1. Example EEMs of the three types of samples at the start (left) and after a weeks storage (right). Top row is the control (Tap water). Middle row is the chlorinated tap water. Bottom row is the chlorinated tap water amended with sulfite. 
Submitted to: Water Research
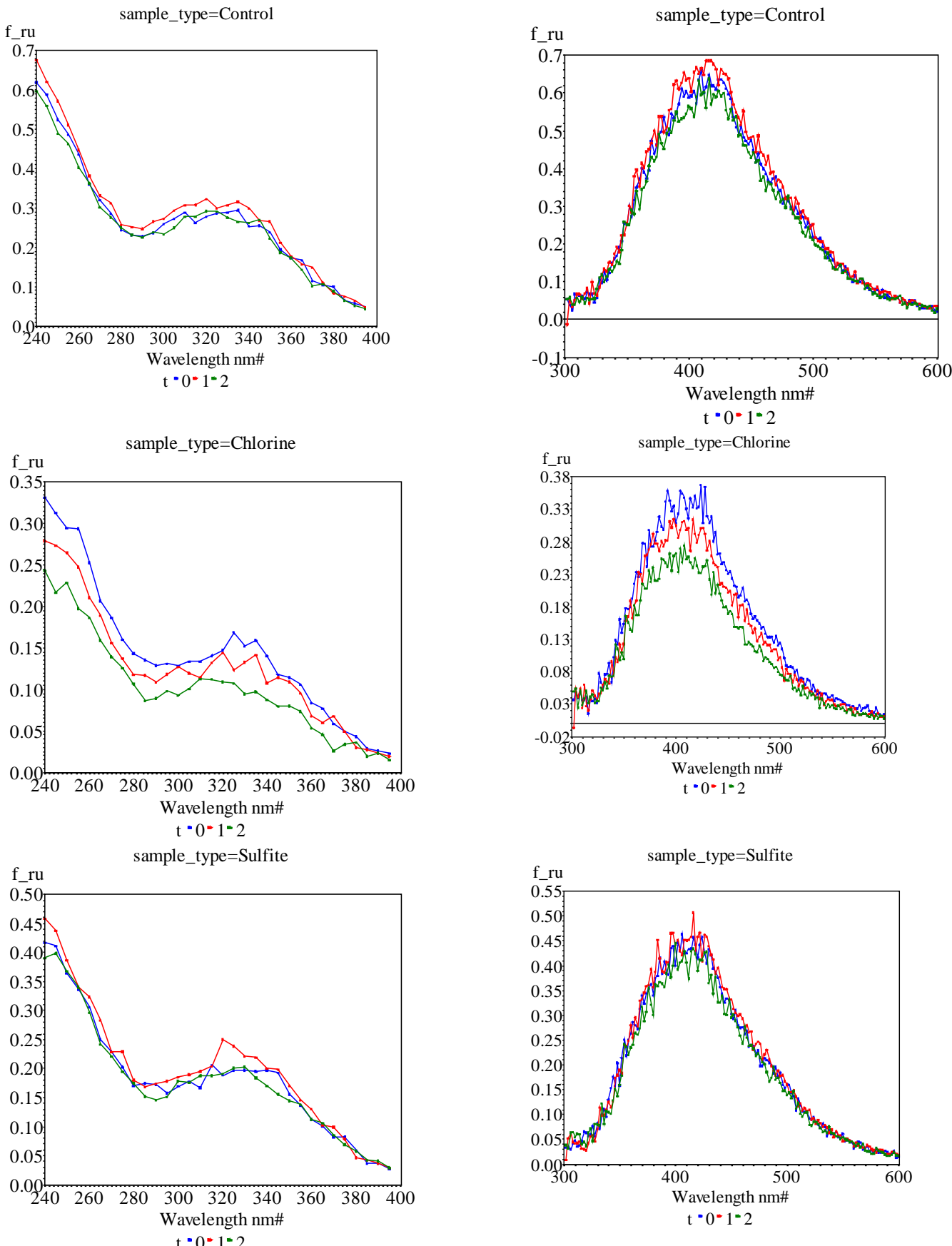

Figure SI-2. Left: The excitation spectra with emission at $420 \mathrm{~nm}$. Right Emission spectra with the excitation set to $240 \mathrm{~nm}$. 
Submitted to: Water Research

571 SI - 2. Kinetic study of fluorescence in swimming pool water with wastewater

572 addition.

573

574 To test fluorescence stability of the swimming pool - wastewater samples, a

575 simple experiment has been performed. A swimming pool water sample with a $0.75 \%$

576 wastewater addition was continuously analyzed within 160 minutes for fluorescence

577 EEM, without refilling the cuvette. The results showed that all components were quite

578 stable within the measurement time (Fig. SI-3.).

579

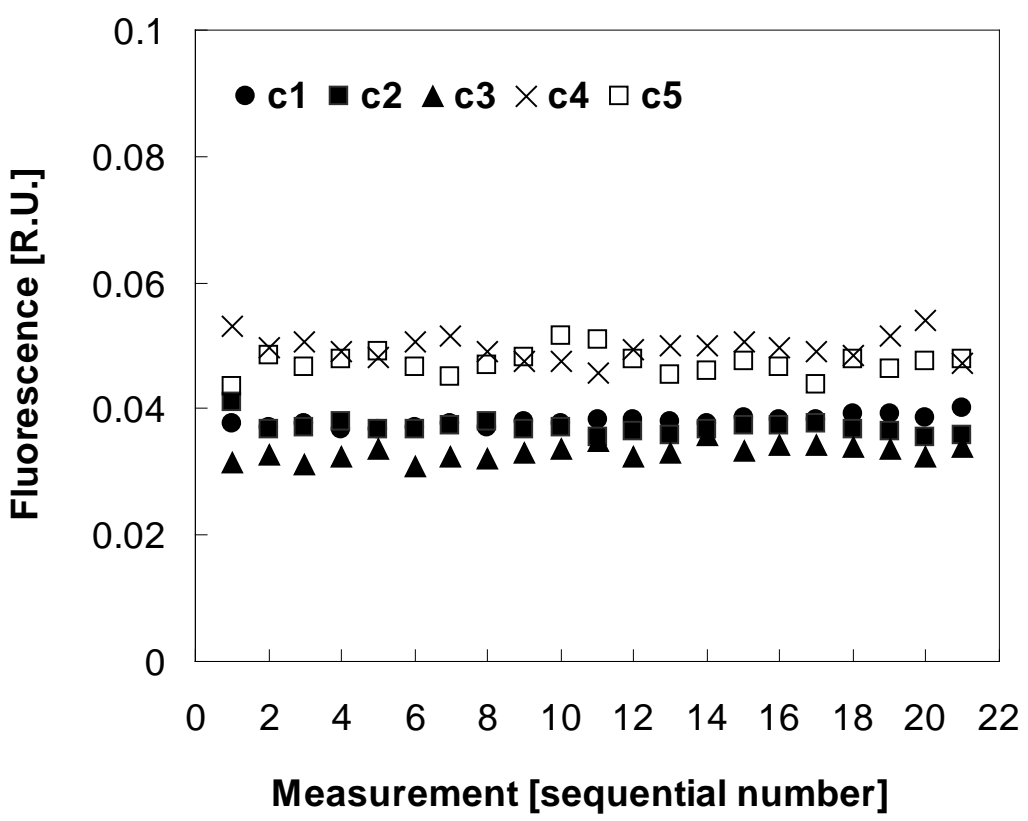

581 Fig. SI-3. Fluorescence intensity of each of the five components (c1-c5) of a swimming 582 pool water sample with $0.75 \%$ wastewater addition, over 21 sequential measurements 583 (approximately $160 \mathrm{~min}$ ).

584

585 The standard deviation values were 2 and 3\% for components 1 and 2, respectively, and $5864 \%$ for components 3-5. 
Submitted to: Water Research

587 An analogous experiment has been performed for MQ water with $0.75 \%$ wastewater 588 addition (fig. SI-4).

589

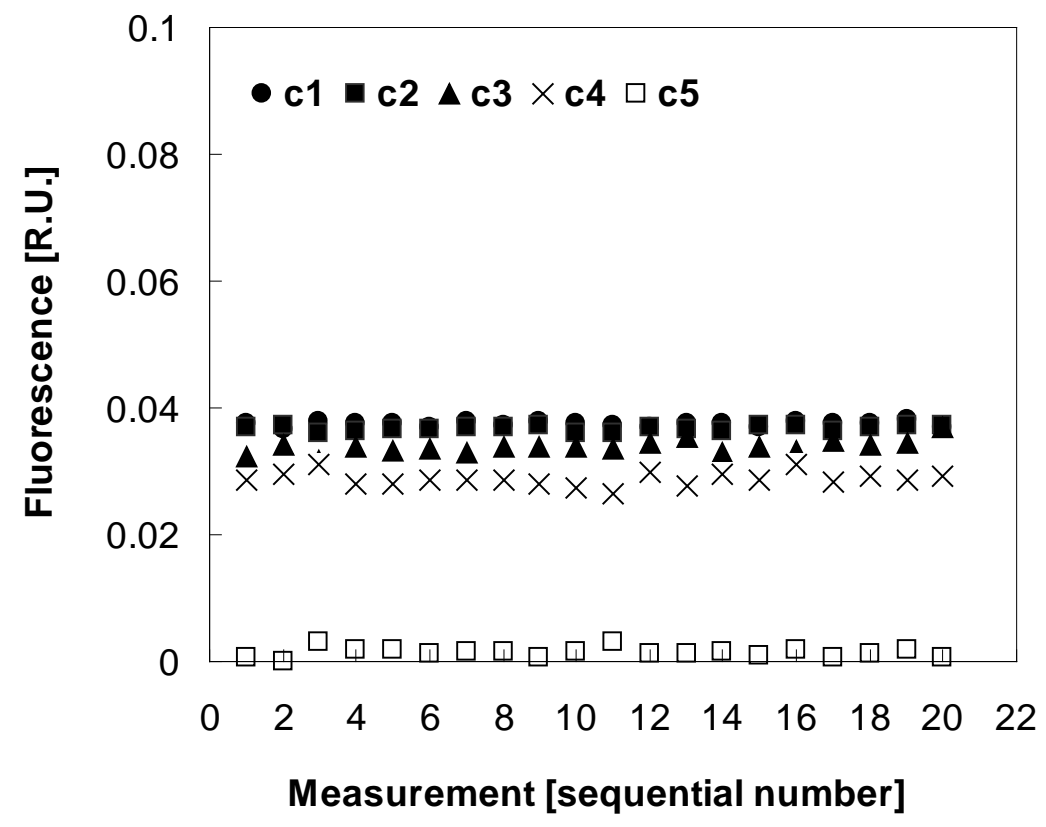

591 Fig. SI-4. Fluorescence intensity of each of the five components (c1-c5) of a MQ water 592 sample with $0.75 \%$ wastewater addition, over 20 sequential measurements

593 (approximately $160 \mathrm{~min}$ ).

594

595 For the MQ water, the standard deviation values were 1\% for components 1 and 2, 3\%

596 for component 3 and $4 \%$ for component 4, thus slightly higher than for the swimming

597 pool sample.

598 
Submitted to: Water Research

599

SI -3- AOX concentration in swimming pool water.

600

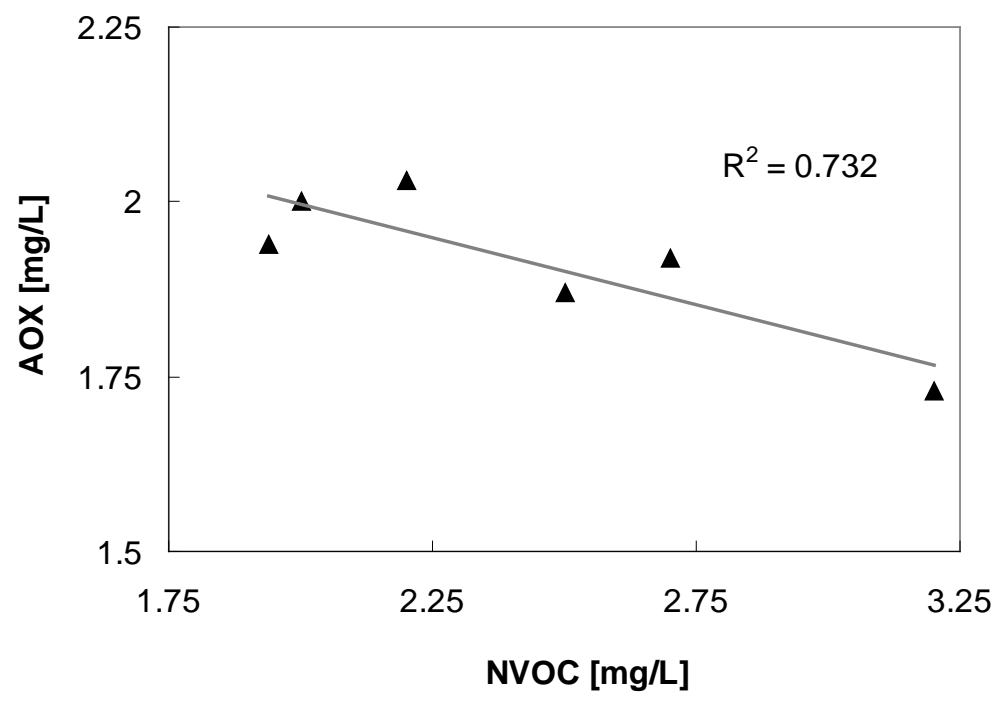

a)

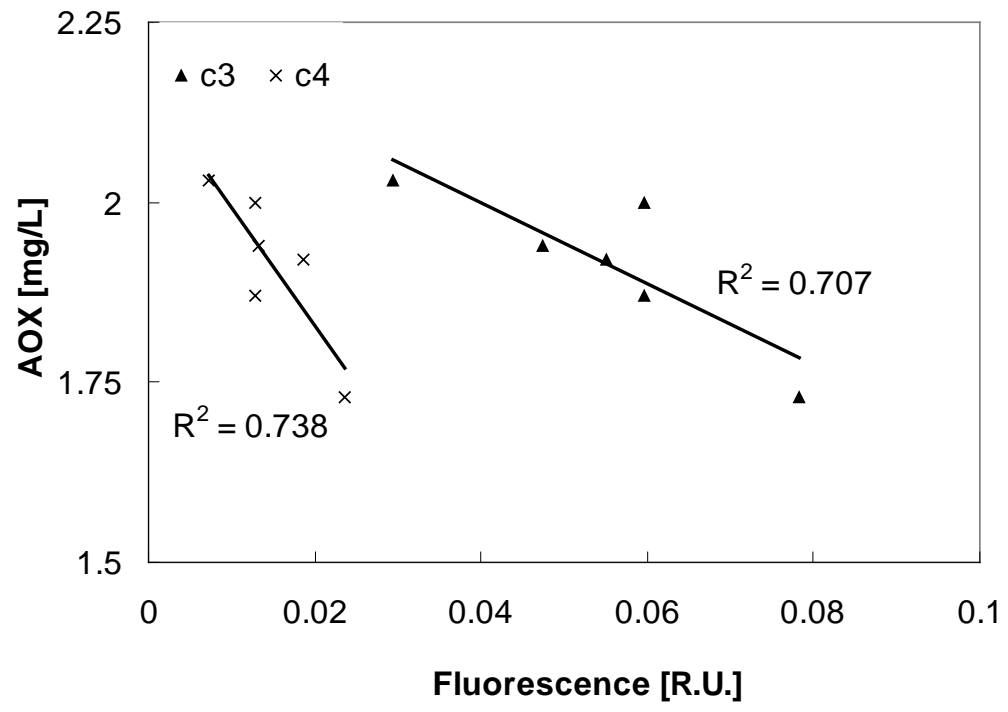

b)

601 Fig. SI-5. (a) NVOC and (b) fluorescence intensity of PARAFAC components 3 and 4 vs. 602 AOX in the warm water swimming pool. 